\title{
Mahendraparvata: an early Angkor- period capital defined through airborne laser scanning at Phnom Kulen
}

Jean-Baptiste Chevance ${ }^{1}$, Damian Evans ${ }^{2,}{ }^{*}$, Nina Hofer ${ }^{1,2}$, Sakada Sakhoeun ${ }^{1} \&$ Ratha Chhean $^{3}$

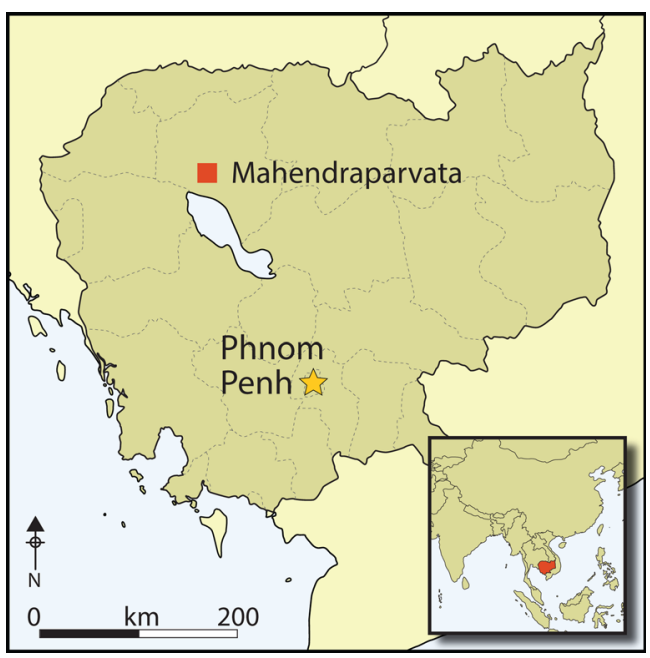

Keywords: Southeast Asia, Angkor, Mahendraparvata, Khmer, lidar, urbanism Angkorian urban areas.

Inscriptional evidence suggests that the Phnom Kulen platean to the north-east of Angkor in Cambodia was the location of Mahendraparvata—an early Angkorian capital city and one of the first capitals of the Khmer Empire (ninth to fifteenth centuries AD). To date, however, archaeological evidence has been limited to a scatter of small and apparently isolated shrines. Here, the authors combine airborne laser scanning with ground-based survey to define an extended urban network dating from the ninth century $A D$, which they identify as Mahendraparvata. This research yields new and important insights into the emergence of

\section{Introduction}

The Angkor region of Cambodia in Southeast Asia (Figure 1) is best known for its monumental temples of brick and stone, such as Angkor Wat, most of which were built between the ninth and thirteenth centuries AD. Recently, interest in the social and environmental context of these temples has grown (Coe \& Evans 2018), with researchers using a range of techniques to illuminate the everyday lives of the people who built them and inhabited the surrounding areas.

\footnotetext{
1 Archaeology and Development Foundation, 25 Brook's Mews, London W1K 4DZ, UK

2 École française d'Extrême-Orient, 22 Avenue du Président Wilson, 75116 Paris, France

3 APSARA National Authority, Bang Korng Village, Ampil Commune, Siem Reap, Cambodia

* Author for correspondence (Email: damian.evans@efeo.net)
}

(C) Antiquity Publications Ltd, 2019. This is an Open Access article, distributed under the terms of the Creative Commons Attribution licence (http://creativecommons.org/licenses/by/4.0/), which permits unrestricted re-use, distribution, and reproduction in any medium, provided the original work is properly cited. 


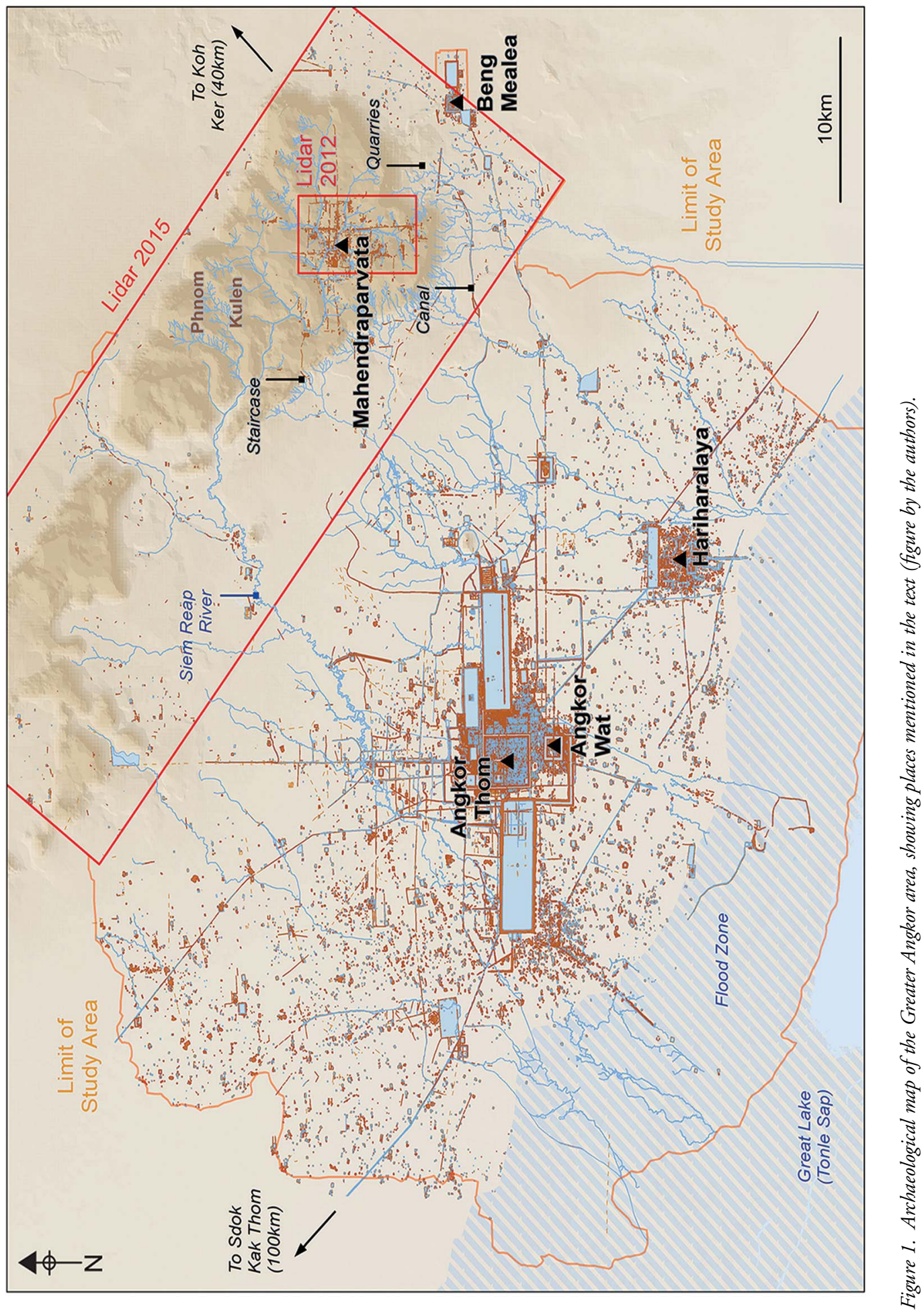

(C) Antiquity Publications Ltd, 2019 
Although Angkorian cities were built of perishable materials that have largely disappeared, they have left, nonetheless, a durable legacy on the surface of the Earth, allowing archaeologists to trace their forms in the contours of the terrain. Our view of the Greater Angkor area has changed considerably in recent years, moving from simple schematic overviews to detailed archaeological maps. The latter reveal a formally planned, densely inhabited urban core surrounded by an extensive network of low-density neighbourhoods, water-management systems, agricultural networks and transportation links to settlements around other major temple sites (Evans et al. 2007, 2013; Evans 2016).

Despite its importance as the location of one of the Angkor period's earliest capitals, the mountainous region of Phnom Kulen has, to date, received strikingly little attention. It is almost entirely missing from archaeological maps, except as a scatter of points denoting the remains of some brick temples. The history and geography of the area has amplified many of the problems of conducting archaeological survey and mapping in Cambodia: until recently, the site was remote, difficult to access and covered with dense vegetation. Furthermore, it was among the last bastions of the Khmer Rouge, who occupied the area from the early 1970s until the late 1990s. Dangerous remnants of war, such as land mines, remain a serious problem. For these reasons-as well as the absence of monumental remains on the scale of Angkor-Phnom Kulen has mostly escaped the attention of researchers (Chevance 2011).

Nonetheless, the area is crucial for understanding the historical trajectory of Angkor and the Khmer Empire, which dominated much of mainland Southeast Asia between the ninth and fifteenth centuries AD (Jacques \& Lafond 2007). It is the source of much of the water that flows into the vast hydraulic network of Angkor on the plain below, and Angkorian inscriptions suggest that the mountain plateau (Figure 2) was the site of one of the capitals of Jayavarman II, whose eighth- to early ninth-century $\mathrm{AD}$ reign marks the beginning of the Angkor period (Stern 1932). This would place the site among the first engineered landscapes of the era, offering key insights into the transition from the pre-Angkorian period, including innovations in urban planning, hydraulic engineering and sociopolitical organisation that would shape the course of the region's history for the next 500 years.

To address this lacuna in the archaeology of Angkor, we undertook intensive survey and excavation programmes on Phnom Kulen in order to understand the spatial and chronological dimensions of Angkor-period occupation (Chevance 2011, 2013, 2014, 2015; Penny et al. 2014). The development of archaeological maps has been enhanced considerably by the application of airborne laser scanning (lidar) techniques in two separate campaigns: the first in 2012, by the Khmer Archaeology LiDAR Consortium, and another in 2015, by the Cambodian Archaeological Lidar Initiative (Evans et al. 2013; Evans 2016). Here we report, for the first time, the detailed results of these aerial mapping campaigns, alongside further insights from work on the ground that speak directly to broader issues in the archaeology of the Angkorian world.

\section{Background}

The principal massif of the Kulen range, located $30 \mathrm{~km}$ from major temples such as Angkor Wat, is an elongated plateau oriented north-west to south-east. Measuring $25 \mathrm{~km}$ along its

(C) Antiquity Publications Ltd, 2019 
Jean-Baptiste Chevance et al.
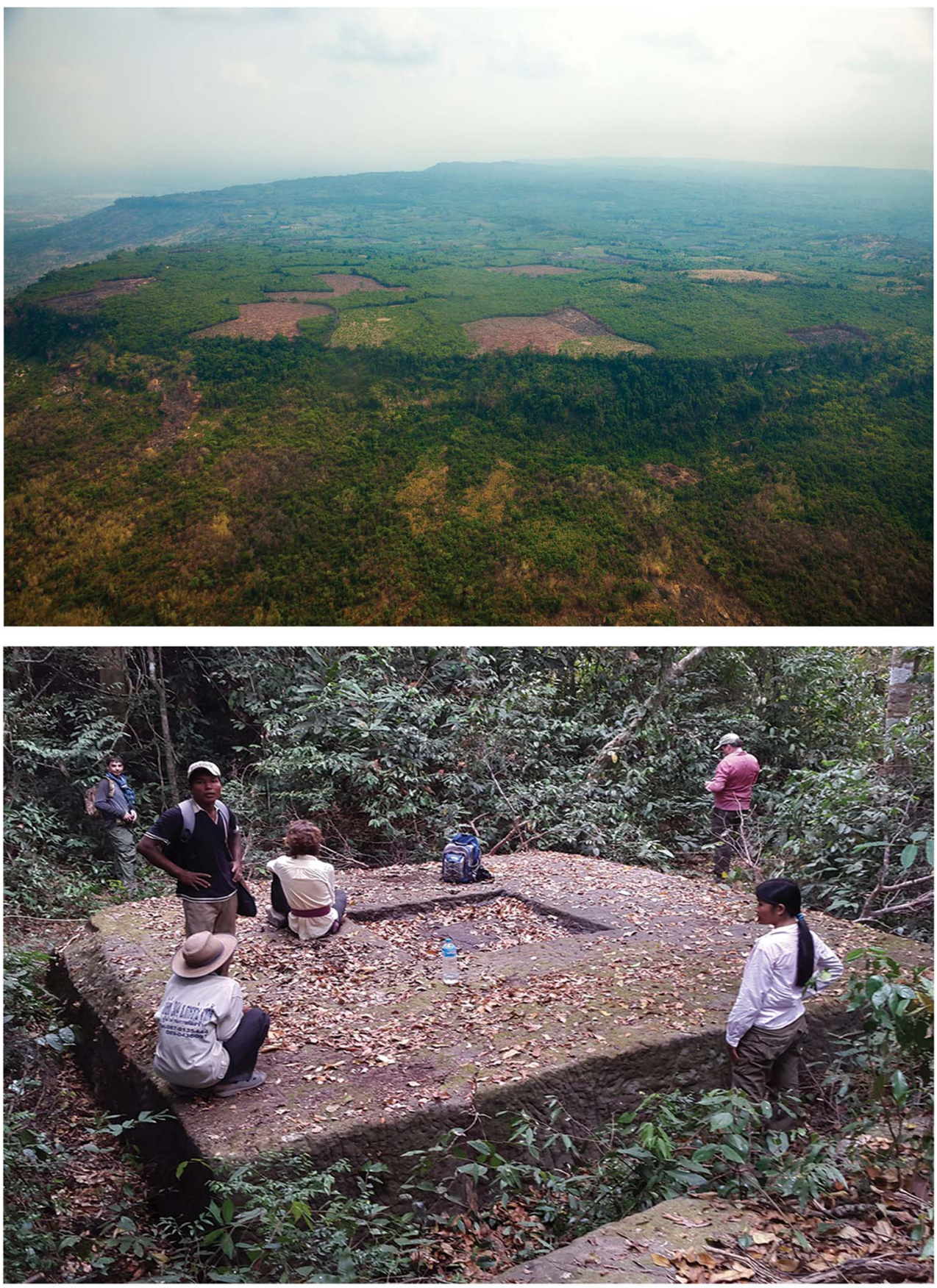

Figure 2. Top) an oblique aerial view of the Phnom Kulen escarpment and plateau (photograph courtesy of the Archaeology Development Foundation); bottom) an example of a newly documented temple site in the forests of the Phnom Kulen region (photograph courtesy of the Cambodian Archaeological Lidar Initiative).

(C) Antiquity Publications Ltd, 2019 
main axis and $15 \mathrm{~km}$ at its widest point, the plateau rises abruptly to an average of $300-400 \mathrm{~m}$ asl above the surrounding flat plain, with margins marked on all sides by steep escarpments (Figure 2). Its forest and permeable stone play an important role in the area's watershed: it is the source of all three of Angkor's main watercourses (Kummu 2009). The marked seasonality of the monsoon is attenuated somewhat by permanent water flows, forest cover and the relative altitude of the mountain. Together, these create a consistently humid microclimate. Soils are shallow, marginal and unsuited to intensive rice agriculture. Traditionally, slash-and-burn rice agriculture is practised here among the semi-evergreen Dipterocarp forest, an ecosystem that is rapidly disappearing despite the region's designation as a National Park (Boulbet 1979; Singh et al. 2018).

The link between this massif and an Angkorian city referred to in Angkorian inscriptions as Mahendrâdri or Mahendraparvata ('mountain of great Indra') was initially proposed at the beginning of the twentieth century (Aymonier 1900: 425, 1904: 470-71; Finot 1911: 2325 ), but proved difficult to confirm due to confusion about royal lineages and the construction sequences of the monuments. Eventually, Stern (1932: 522) identified the temples of Phnom Kulen as dating to the ninth-century reign of Jayavarman II, and proposed that the royal city of Mahendraparvata would also be found on the massif. Although Stern $(1936,1938)$ surveyed the area, evidence for Mahendraparvata remained elusive. Nonetheless, his mission generated the first archaeological map of the massif, including the locations of numerous newly documented temples. Stern's map-comprising, essentially, a scatter of points in the jungle-would remain the definitive image of the area for decades to come.

The 1960s saw renewed interest in the region. Hansen (1969) and Boulbet (Boulbet \& Dagens 1973; Boulbet 1979) added various elements to Stern's archaeological map, in particular water-control structures, dykes and other linear features, without necessarily adding support to the notion of an urban network. Aerial mapping campaigns of the Angkor region throughout the 1990s extended northward to the mountains, but with limited success. While radar imaging provided additional detail around the base of the mountain range, the dense foliage could not be penetrated, and Phnom Kulen remained a lacuna on archaeological maps (Evans et al. 2007).

More recently, major advances have been made following ground investigations (Chevance 2011, 2013, 2014, 2015), which have identified certain elements characteristic of urban form, and, specifically, of an Angkorian capital city. Notable among them is the temple of Rong Chen, the distinctive pyramidal shape of which is typical of other state temples located at the heart of pre-Angkorian and Angkorian urban areas. Further compelling evidence is the identification of a royal palace site close to Rong Chen, at the site of Banteay (Chevance 2015). Its distinctive rectangular shape, size, orientation and architectural remains indicate that it was the centre of power of a royal capital. This was confirmed through excavation, which also provided radiocarbon dates consistent with the reign of Jayavarman II in AD 770-835. Simultaneously, however, this work further underscored the limitations of conventional survey and mapping techniques in areas of tropical forest, and a coherent vision of the city itself remained elusive. It was in this context that airborne laser scanning was deployed in order to exploit its unique ability to 'see through' vegetation and provide high-resolution models of the forest floor (Evans et al. 2013). Here, we confirm the hypothesis, based on this accumulated body of evidence, that Mahendraparvata-the

(C) Antiquity Publications Ltd, 2019 
eighth- to ninth-century AD capital of the Khmer Empire-was located on the Phnom Kulen massif.

\section{Methods}

Aside from temples, urban areas in the Angkorian world were constructed principally of wood and other perishable materials, which creates obvious challenges for researchers seeking to identify elements of past urban forms. Since the 1990s, however, a number of studies have confirmed that interpretation of microtopographic variations is a practical method for identifying and mapping remnant traces of the built environment, such as mounds, ponds, fields, walls, roads and canals (Evans et al. 2007). Our initial acquisition of Phnom Kulen lidar data took place in 2012 using methods detailed by Evans et al. (2013). Our target coverage area included the principal archaeological features described above, covering $30 \mathrm{~km}^{2}$; by processing data collected at the ends of flight lines, a total of $\sim 37 \mathrm{~km}^{2}$ was achieved. The second acquisition took place in 2015 using methods described by Evans (2016), and covered the entire mountain range (including overlapping coverage of the 2012 area) with a total area of $975 \mathrm{~km}^{2}$ (Figure 1).

The results of survey, mapping and excavation campaigns prior to the lidar acquisitions (Stern 1936, 1938; Hansen 1969; Boulbet \& Dagens 1973; Boulbet 1979; Chevance 2011) were digitised and consolidated in a geographic information system (GIS), using a geodatabase schema based on the archaeological mapping classification developed by Evans et al. (2007) for Greater Angkor. We used ArcGIS 10 software to process the ground-classified points into a series of raster products for analysis, including digital terrain models, hillshade models, local relief models and sky-view factor models (Kokalj \& Hesse 2017). These were analysed systematically and collaboratively by a team of archaeologists and geographers, and mapped into an ArcGIS geodatabase using 'heads-up' digitising.

Between 2012 and 2017, a total of 598 newly documented features were visited on the ground. Topographic variation was observed to assess concordance with the lidar elevation model. We also documented the presence of surface archaeological remains, which comprised mostly ceramic material and, less frequently, bricks or sandstone pedestals that typically indicate temple sites. In rare cases, field investigations were required to eliminate natural geological formations (in particular, rocky outcrops) and bomb craters from our analysis. Finally, the geodatabase was updated and modified to incorporate our field investigations and produce archaeological maps of the plateau (Figures 3-6).

\section{Results}

\section{An urban network}

The most striking result of the lidar survey is the discovery of a framework of linear axes, oriented roughly to cardinal directions and spanning much of the southern area of the plateau (Figure 3). The axes consist of one, two or sometimes three parallel linear topographic anomalies, which are subtle and difficult to observe on the ground. These anomalies consist predominantly of raised earthen embankments with an elevation profile of $<1 \mathrm{~m}$. Certain stretches of the embankments are replaced by shallow linear trenches of $<1 \mathrm{~m}$. The axes are

(C) Antiquity Publications Ltd, 2019 


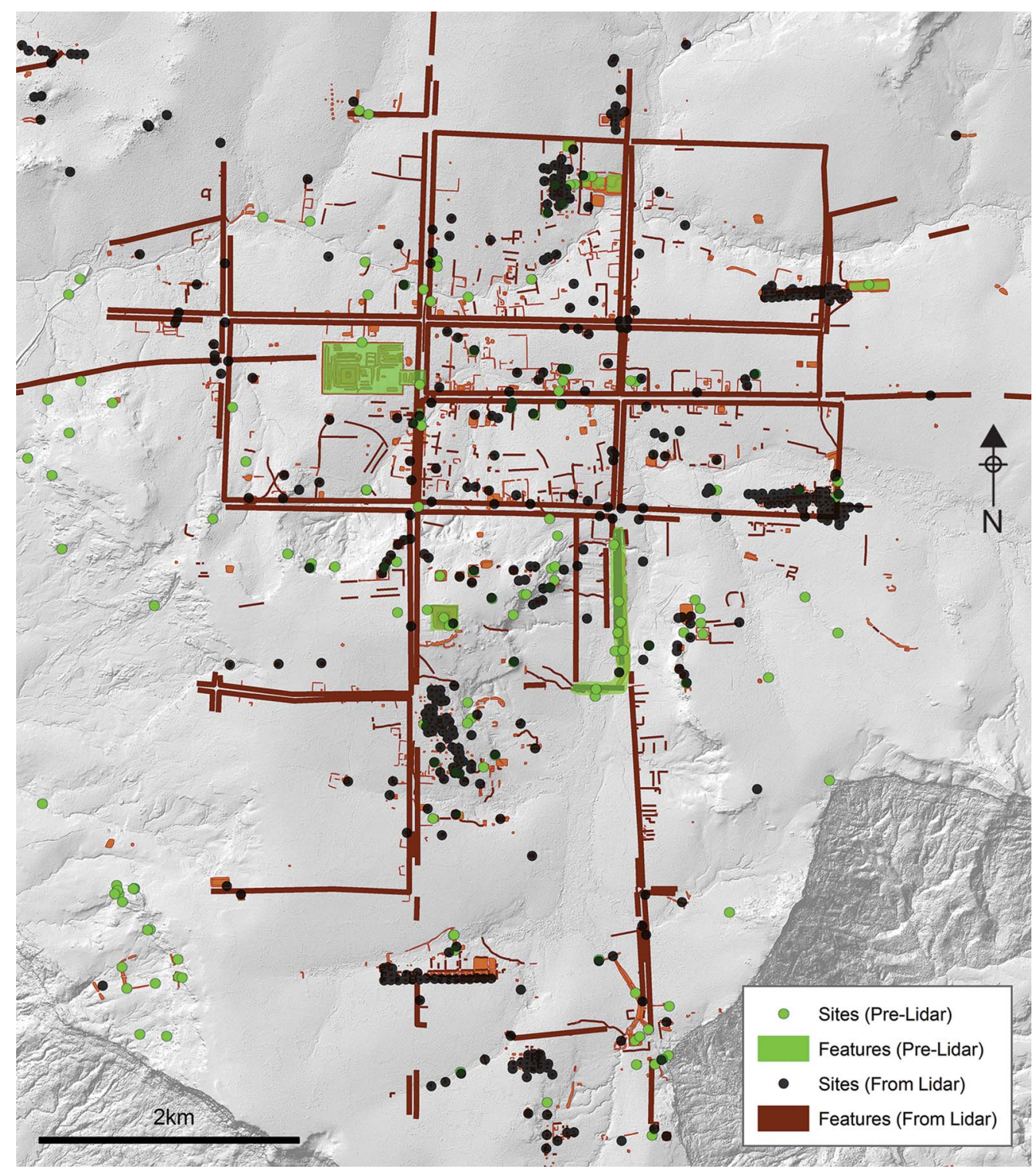

Figure 3. Map showing the newly discovered main axes of Mahendraparvata, and comparing the pre-lidar and post-lidar mapping (figure by the authors).

most clearly defined in the central grid area, where they usually comprise two parallel earthen embankments separated by a distance of $60-80 \mathrm{~m}$. During field investigations in 2014 , an $80 \mathrm{~m}$-long trench was opened through a cross-section of one of these central axes to reveal the subsurface stratigraphic profile. We found that the space between the two embankments comprised layers of soils that may have been deposited to level the ground between them. Originally, each of the embankments had a trench on at least one side that are now filled in - probably borrow pits (cavities that remain after soil and other material has been excavated

(C) Antiquity Publications Ltd, 2019 


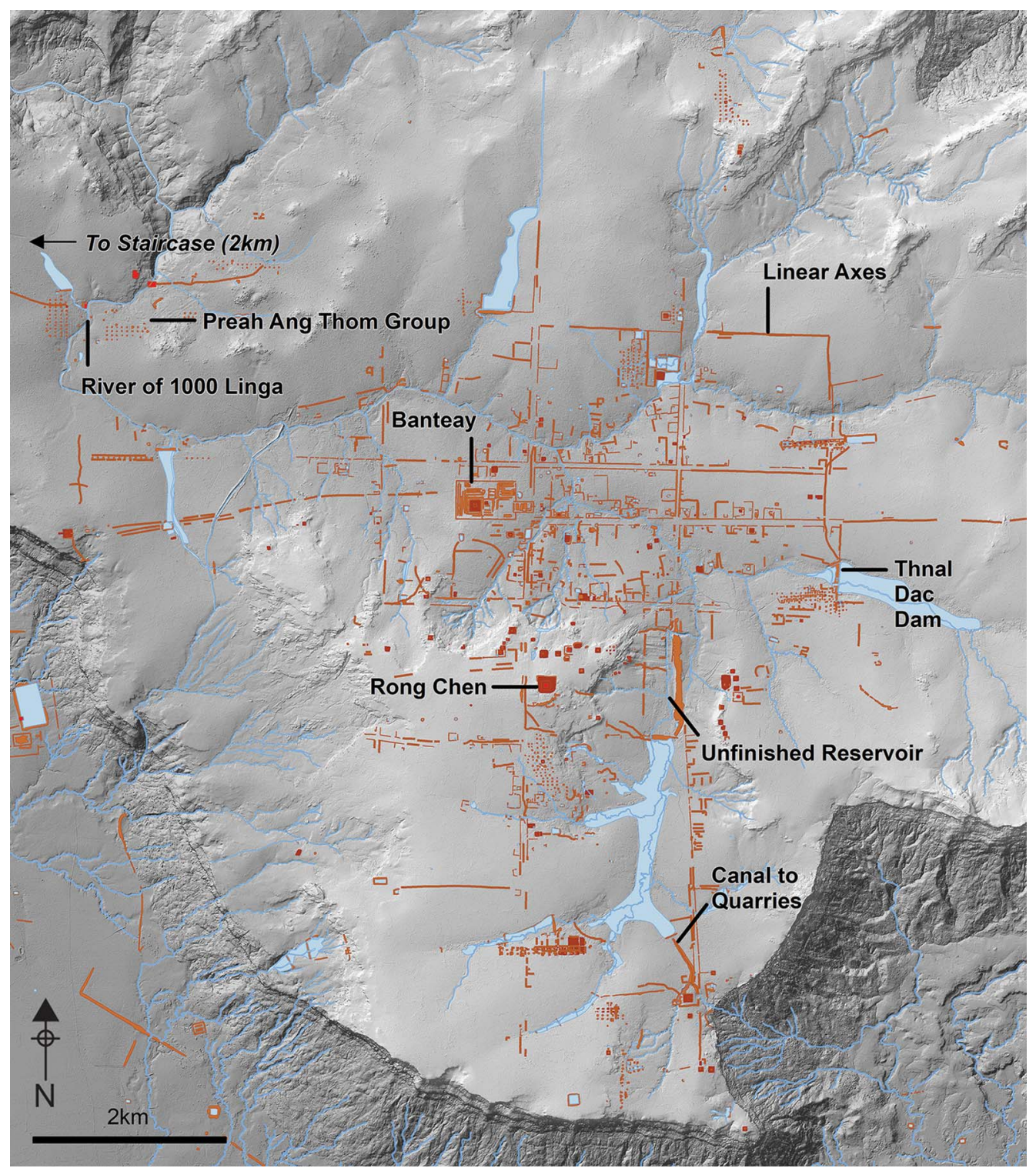

Figure 4. Map of Mahendraparvata on top of a lidar-derived hillshade model (figure by the authors).

and re-used elsewhere-typically for construction projects) created at the time of their construction; these trenches yielded eighth- to ninth-century AD ceramic material. No bricks or other architectural remains were discovered in our excavations or surveys of these axes.

The longest north-south axis is $\sim 10 \mathrm{~km}$ in length, and the longest east-west axis stretches $\sim 15 \mathrm{~km}$. This network of axes integrates a developed area covering some $40-50 \mathrm{~km}^{2}$ and defines a central grid divided into square parcels of $\sim 1.5 \mathrm{~km}$ on each side. We can identify four major north-south axes, although the most westerly is fragmentary and visible only in (C) Antiquity Publications Ltd, 2019 


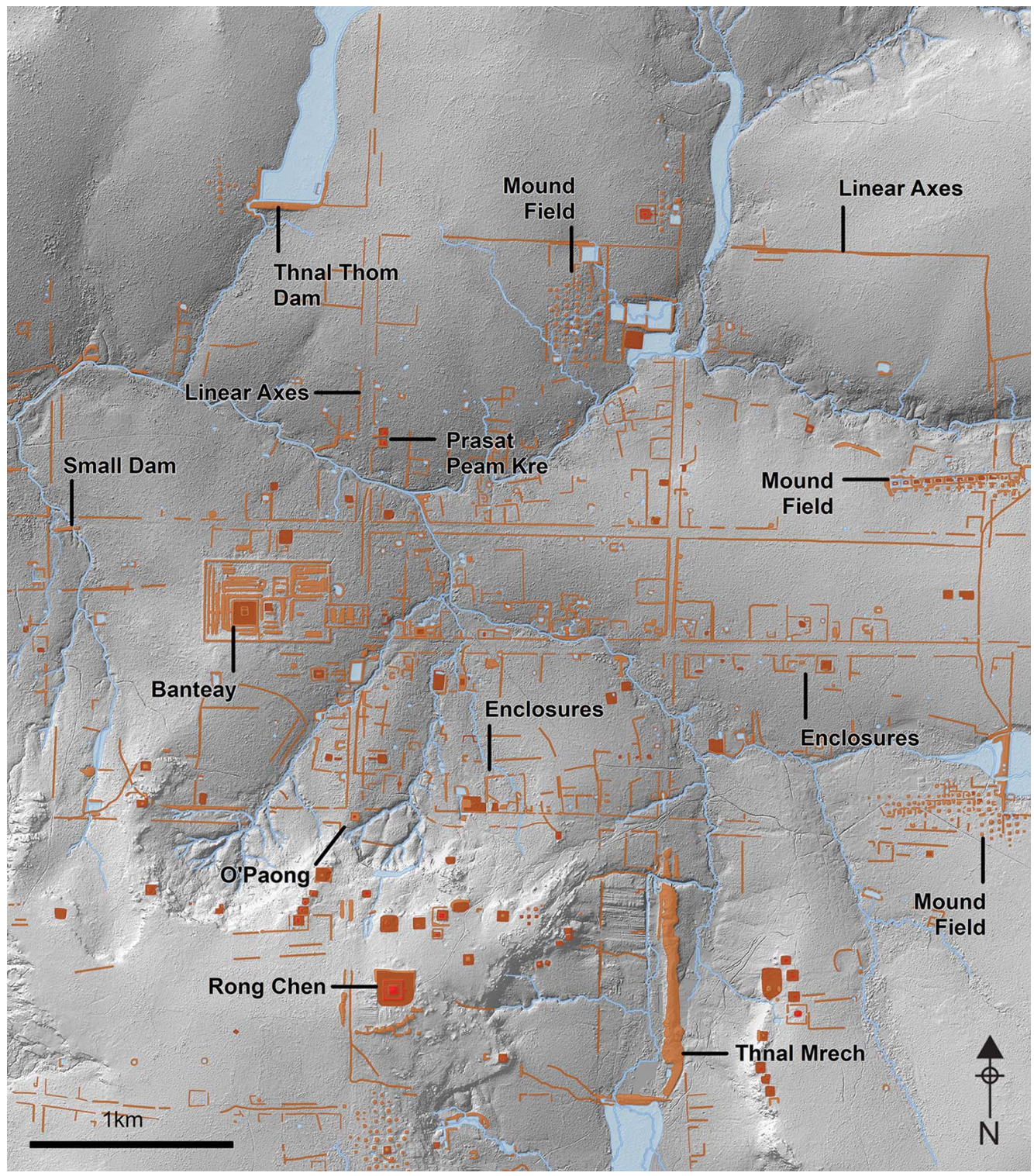

Figure 5. Map of the central grid of Mahendraparvata on top of a lidar-derived hillshade model (figure by the authors).

certain sections. Six more axes run east-west, although the southernmost two are also fragmentary. The longest east-west axis is anomalous in placement and structure, as it does not conform to the grid; rather, it connects the palace site of Banteay with areas far to the east and west.

Numerous other elements of the anthropogenic landscape connect to this broader network, suggesting the elaboration of an overall urban plan. Dams, reservoir walls and the enclosure walls of temples, neighbourhoods and even the royal palace abut or coincide with the embanked linear features. Some major axes terminate in features such as ponds

(C) Antiquity Publications Ltd, 2019 


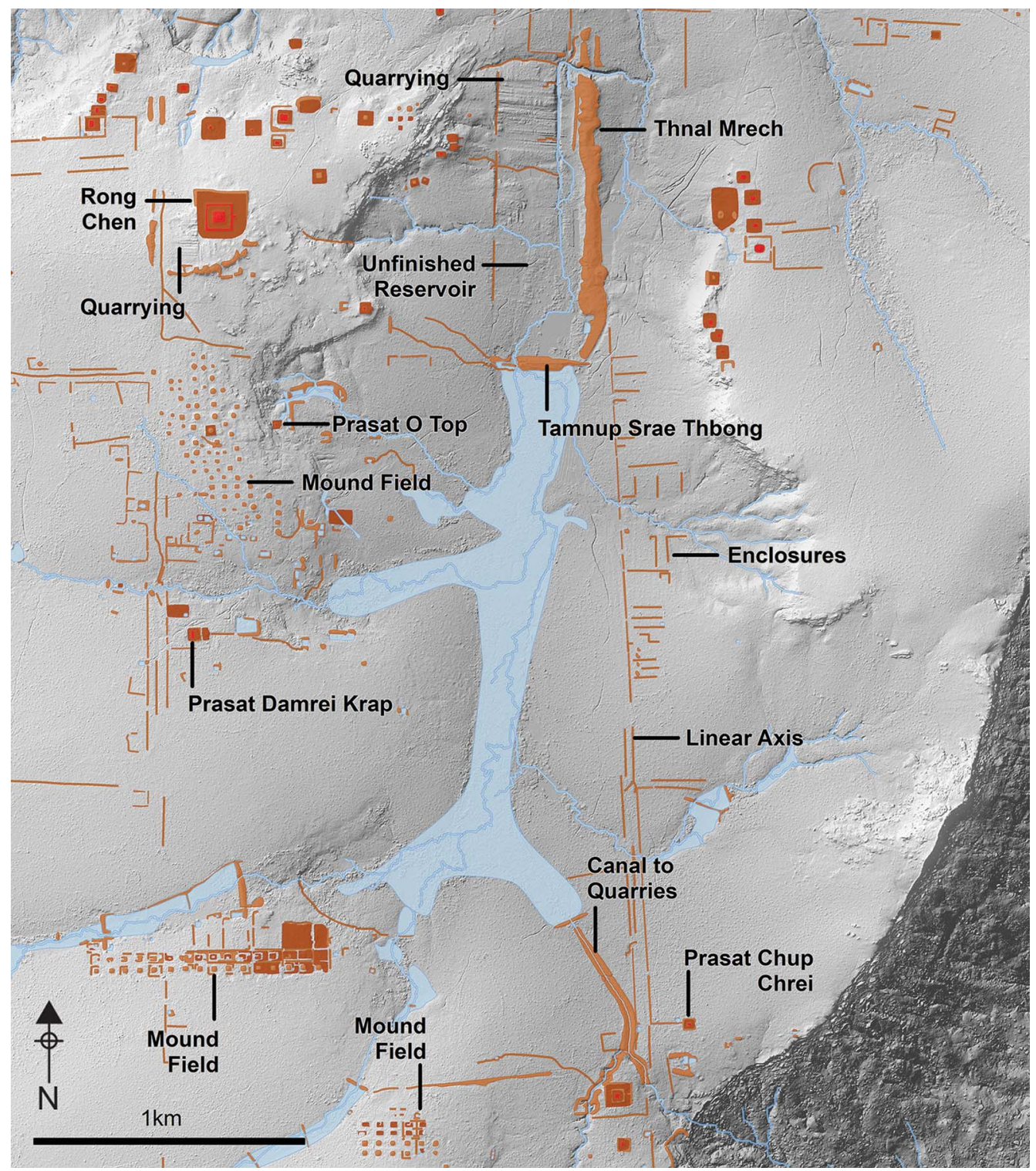

Figure 6. Map of the southern area of Mahendraparvata on top of a lidar-derived hillshade model (figure by the authors).

and temples, while other sites have smaller causeways linking them with the major axes. One temple, O'Paong, is located at the intersection of two major axes (Figure 5) - apparently by design: it sits at the halfway point on the axis that connects the palace site of Banteay with the state pyramid temple of Rong Chen.

Most of the elements we mapped in Phnom Kulen are aligned with the major axes, although it is difficult to read too much into this, given the general preference for cardinal (C) Antiquity Publications Ltd, 2019 
orientation in the Angkorian world. On the other hand, Angkorian temples conventionally face towards the east, and the newly discovered axes help to explain the anomalous westward orientation of several Phnom Kulen temples. These actually open towards the axes (e.g. Prasat Peam Kre; Figure 5) and, in the case of westward-facing Prasat Chup Crei (Figure 6), the temple is even linked directly to an axis by a causeway.

The grid on Phnom Kulen does not appear to be directly connected to broader, regional transportation or communication networks. The well-known stone stairway of Denh Cho (or Phleu Cèrè) that scales the Phnom Kulen escarpment is considered to be the main access point between Jayavarman II's capital and the Angkor plains below. The lidar imagery, however, reveals that this stairway is located to the north-west of the Mahendraparvata urban framework (Figure 1). Instead, Phleu Cèrè leads to the tenth- to twelfth-century AD Preah Ang Thom group on Phnom Kulen (Figure 4), which is substantially later than the main Mahendraparvata complex. The lidar data therefore offer new insights into the spatio-temporal complexity of Phnom Kulen, to which we return below.

\section{Hydraulic infrastructure}

Exploration and mapping by Stern in the 1930s revealed the existence of Tamnup Srae Thbong and Thnal Mrech-two massive earthen dykes on Phnom Kulen (Figure 6), which join to form an L-shape. Additionally, surveys in the 1960s identified and mapped a system of smaller earthen dams built across river valleys (Hansen 1969). These hydraulic features are clearly recognisable in the lidar imagery, and we were able to revise existing maps to increase clarity and precision.

These hydraulic features are well integrated into the grid structure created by the major axes. To the north, the Thnal Thom dam (Figure 5) is located precisely in line with the northernmost east-west axis. A smaller dam to the north-west of the palace site of Banteay is also in line with that axis and permits the crossing of a stream. Thnal Dac, on the east of the central grid (Figures 4-5), and Tamnup Srae Thbong, the massive dyke blocking the plateau's main valley (Figure 6), are also important components of the overall grid layout.

The main natural feature in the southern part of the plateau is a broad, flat, north-south valley. Here, we see evidence of an ambitious project formalising the natural valley into a rectangular water-storage feature. The lidar data show that the L-shaped configuration of Tamnup Srae Thbong and Thnal Mrech form part of a huge, unfinished north-south reservoir, that would have covered an area of $1050 \times 330 \mathrm{~m}$ (Figure 6). The two earthen dykes form its southern and eastern walls, and there is evidence for the removal of bedrock to deepen the reservoir and straighten its western and northern walls. The lidar data reveal a very distinctive pattern of striations in the valley, where soil was dug out of the ground systematically, and then piled up to form the dykes of the reservoir. Had it been finished, the reservoir would have retained water flowing through the valley, forming a rectangular body of water inundating over $35 \mathrm{ha}$. This reservoir would have been precisely integrated into the engineered landscape of Phnom Kulen. Its eastern wall is built into one of the major north-south axes; the temple of Rong Chen sits exactly on its east-west centre line; and to the east of the reservoir, a series of westward-facing temples also sit on that centre line

(C) Antiquity Publications Ltd, 2019 
(Stern 1936). This arrangement recalls the pyramid-reservoir-temple configuration at the tenth-century Angkorian capital at Koh Ker (Evans 2010) (Figure 7).

The lidar elevation data have also clarified the structure and function of a channel located at the southernmost point of the valley (Figures $4 \& 6$ ). Here, the natural direction of flow is to the north, but this $1 \mathrm{~km}$-long structure instead channels water to the south. We also found evidence here for water-control mechanisms, such as sluice gates, carved into the
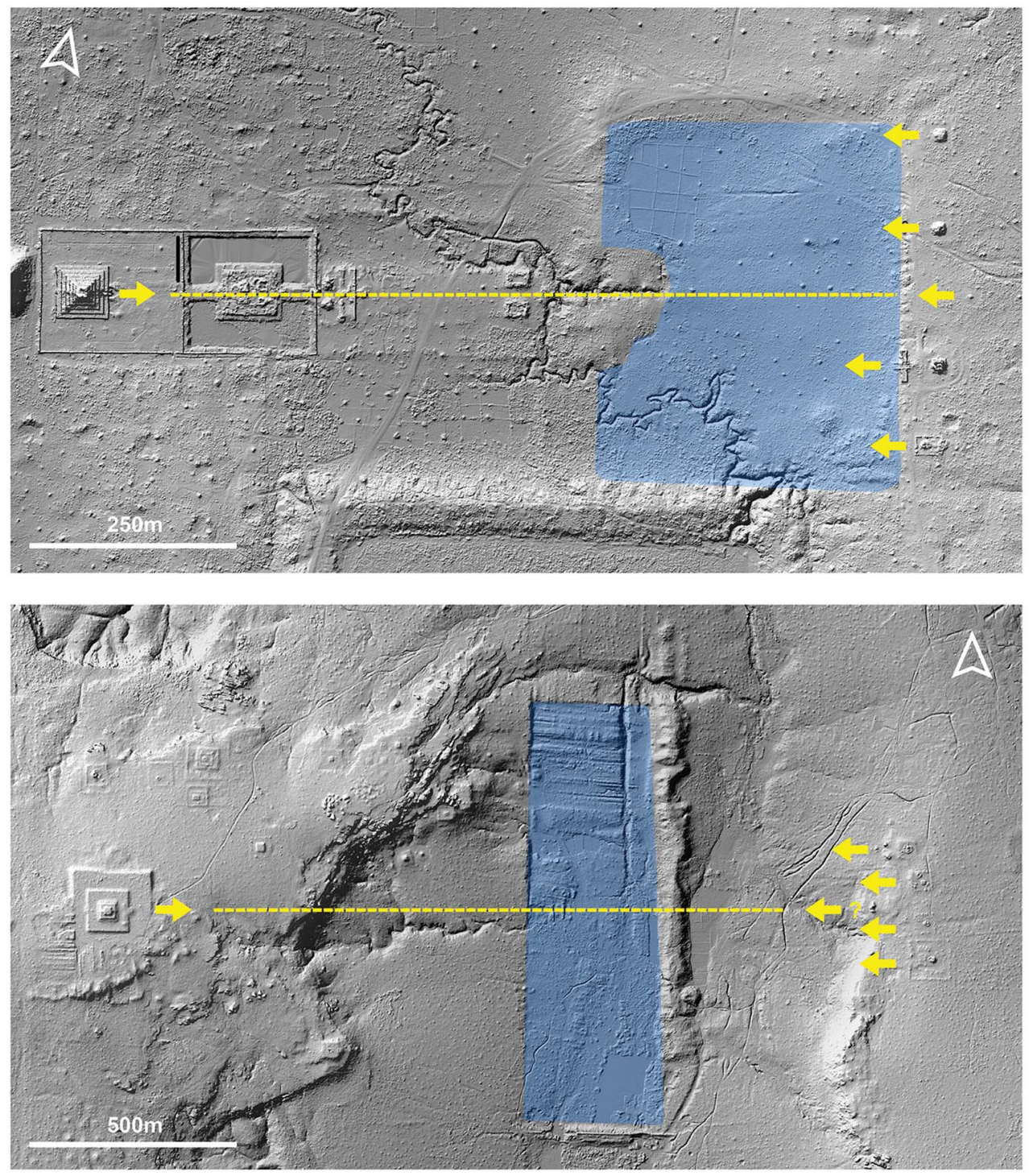

Figure 7. Axis and orientations of the central pyramid, reservoir and associated shrines at Koh Ker (top) and Mahendraparvata (bottom) (figure by the authors).

(C) Antiquity Publications Ltd, 2019 
stone. These structures divert water over the escarpment and down into the area between Phnom Kulen and Beng Mealea, from where sandstone blocks were quarried and transported down canals to build the temples of Angkor (Uchida \& Shimoda 2013) (Figure 1). Lidar imaging has revealed the full extent of quarries in this area, along with dykes for controlling the water required for moving the stones (Evans 2016). We can now see evidence that engineering works on top of the plateau also played a role in this sophisticated hydraulic system.

\section{Habitation}

Although we found little evidence for the type of mound-and-pond-based habitation patterns typical of Angkorian urbanism (Evans \& Fletcher 2015; Stark et al. 2015; Evans 2016), we nonetheless identified a distinctive topographic spatial patterning associated with the main axes-and in particular with the central grid — that we interpret as evidence for habitation. Of particular significance are the presence of numerous earthen enclosures that align roughly with, and often abut, the main axes. These small embankments, of decimetre scale in height and in cross-section, subdivide what we interpret as square 'city blocks' with sides of $1.5 \mathrm{~km}$ in length into an intricate and extensive network of smaller plots with areas normally in the range of 1-4ha (Figures 5-6). These plots are somewhat haphazard in their layout, with inconsistent sizes and orientations. This may represent more organic developments that emerged alongside, and out of, the more formal axes of the central grid, without reaching very far into the interior of the 'city blocks'. A few ponds, mounds and temple sites are scattered throughout. Archaeological excavations undertaken in 2014 and 2016 by the Archaeology and Development Foundation (ADF) confirmed habitation, including organic layers containing eighth- to ninth-century $\mathrm{AD}$ ceramics.

\section{Mound fields}

On Phnom Kulen we found a remarkable collection of 'mound fields': cardinally oriented arrays of earthen mounds that have been previously reported at two locations down in the Angkor plain (Evans et al. 2007). We identified 15 distinct groups (Figures 5-6) on the Phnom Kulen plateau, comprising 366 individual mounds. This represents the most significant concentration of these features so far identified in the Angkorian world. All of these individual mounds were visited on the ground, and we found no surface evidence of associated architectural or ceramic remains. In 2013, ADF excavated four mounds from two different groups, revealing little of archaeological interest. Thus, their meaning and function remain unclear, although we can be reasonably confident that they did not function as funerary structures, habitation mounds or architectural foundations. Excavations at a mound field in Angkor by the Greater Angkor Project were similarly inconclusive (Martin Polkinghorne pers. comm.). The excavations in Phnom Kulen, however, yielded ceramics and evidence for construction radiocarbon-dated to the tenth century $\mathrm{AD}$. This is consistent with our observation that, in many areas, the mound fields of Phnom Kulen seem to have been laid out with little consideration for Mahendraparvata's original spatial structure, and may, therefore, substantially post-date the initial period of major development. 


\section{Discussion}

Analysis and interpretation of the lidar data has revealed thousands of features of archaeological interest, extending across an area of $40-50 \mathrm{~km}^{2}$. This immediately raises questions concerning chronology. The first point to note is that the grid of major axes provides the overall framework upon which other patterns of habitation are based and elaborated. Enclosures often have at least one wall aligned with or abutting a major axis, yet no enclosure intrudes upon or interrupts one of the axes, suggesting a coherent overall design. Furthermore, although we found hundreds of ponds within the central area, only two of them interrupt the course of the major axes; the other ponds are scattered within the city blocks. We see no evidence of earlier constructions beneath or within the major axes, or any other indication that this vast, formal grid was superimposed upon a pre-existing settlement. All of this evidence suggests that the central grid was laid out before, or during, the elaboration of the habitation network, and that the two systems functioned contemporaneously.

The network of Phnom Kulen therefore mostly developed according to an overall plan, and the major axes, including the largest earthen dams, were the earliest and most fundamental elements of that design. As noted, the monumental architecture of Phnom Kulen also conforms neatly to that spatial framework; as those temples are known to date to the late eighth- to early ninth-century AD reign of Jayavarman II, we interpret this as evidence of a contemporaneously functioning, formally planned urban network. This functional and chronological interpretation is consistently supported by field observations and, in particular, ceramic material and radiocarbon dates from securely stratified contexts.

Importantly, two temples in Phnom Kulen that have long been thought to pre-date the reign of Jayavarman II-Prasat Damrei Krap and Prasat O Top (Chevance 2011: 150-62) - are conspicuously out of alignment with the urban grid (Figure 6). Notable among the other misaligned features are the 'mound fields' or gridded arrays of mounds, which we believe probably date from the tenth century AD. This suggests a long and complex history for Mahendraparvata following its late eighth- to early ninth-century tenure as a capital, involving periods of renovation and transformation. These, in turn, accord with inscriptions that attest to the continued use of Phnom Kulen as a site of worship and pilgrimage throughout the Angkor period (Chevance 2013, 2014), and also with local palaeobotanical records suggesting extensive and intensive human land use from the eighth to twelfth centuries AD (Penny et al. 2014).

Mahendraparvata is also notable for its lack of rice-field walls and occupation mounds, compared with the lowland areas of Greater Angkor. As these are both Khmer adaptations to floodplain environments, it is unsurprising that they are not abundant in the gently rolling upland topography of Phnom Kulen. The tenth-century AD capital of Koh Ker, $50 \mathrm{~km}$ to the northeast of Phnom Kulen, has a similar topography, and occupation mounds are also largely absent from the archaeological record there, while relict rice-field walls are scarce (Evans 2010). Yet, epigraphic and other evidence also confirms that Koh Ker was both an urban centre and a capital of empire. While achievements in hydraulic engineering are relatively modest at Mahendraparvata, lidar imagery clearly shows that an ambitious programme was initiated, but never completed. Even if it was never functional, the reservoir at Mahendraparvata was a prototype for the vast artificial lakes that would become a defining feature of later Angkor.

(C) Antiquity Publications Ltd, 2019 
For a number of reasons, Mahendraparvata therefore represents an important milestone in the development of urban form in the region (Figure 8). Prior to the site's construction in the eighth century $\mathrm{AD}$, the evidence shows that settlement patterns in the Angkor region comprised small, loosely structured urban areas that lacked any formal grid, had no clear boundaries and appear to have developed organically without a coherent plan (Pottier 2017). Beyond the Angkor region, a handful of centres show evidence of enclosing walls;
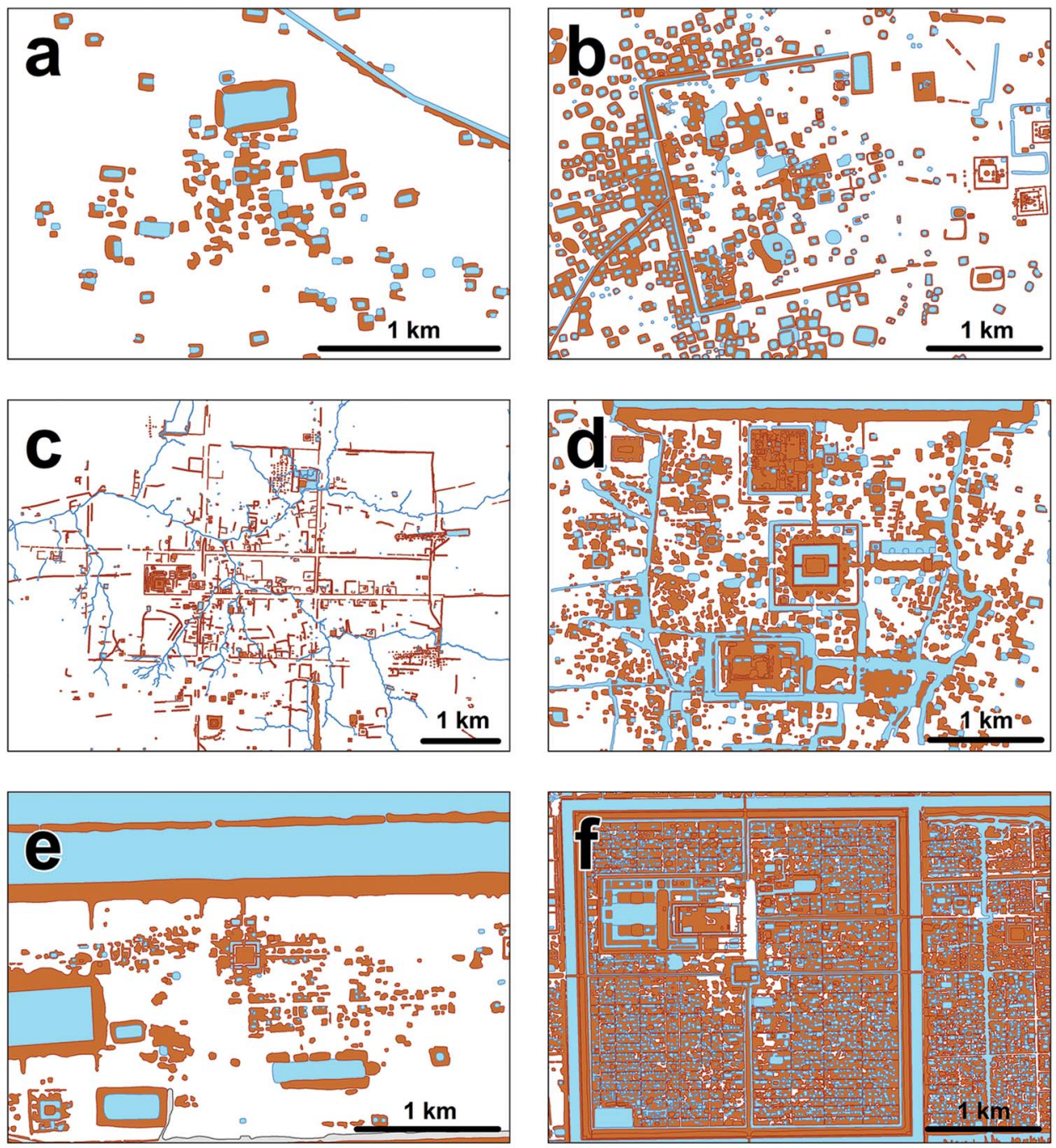

Figure 8. The development of urban form in the Khmer world: a) pre-Angkorian 'open settlements' of the sixth to eighth centuries AD; b) the pre-Angkorian capital of Sambor Prei Kuk, sixth to eighth centuries AD, with 'enclosure' wall; c) the gridded city of Mahendraparvata, eighth to ninth centuries AD; d) the early Angkorian capital of Hariharalaya, ninth century $A D ; e$ ) the capital of Rajendravarman at Angkor, tenth century AD; $f$ ) the gridded city of Angkor Thom, eleventh to thirteenth centuries $A D$ (figure by the authors).

(C) Antiquity Publications Ltd, 2019 
for example, at the sixth- to eighth-century AD site of Sambor Prei Kuk (Shimoda 2010). But these are much smaller in scale than at Mahendraparvata, and contain no internal grids. Thus, Mahendraparvata marks an important point of departure, and appears to represent the first large-scale 'grid city' elaborated in the Khmer world.

It would be some time before such a design would be fully realised again in the Angkor region (Figure 8 ). The ninth-century $\mathrm{AD}$ city of Hariharalaya - the capital immediately following Mahendraparvata — contains a monumental core but, overall, evinces an organic layout typical of the early Angkorian 'open cities' (Evans 2010; Pottier 2012). It is only in the tenth and eleventh centuries $\mathrm{AD}$ that the massive linear axes and internal frameworks of cities appear again in the Angkor region (Gaucher 2017), and not until the twelfth century that we have unambiguous evidence for gridded cities achieved on the same scale as Mahendraparvata (Evans 2016). Hence, the urban network revealed by lidar and described here seems to form an enormous and remarkably early experiment in formal urban planning. The urban model that first developed on this mountain plateau, although sparsely inhabited at the time and not widely adopted straight away, would eventually be adapted to the low-lying floodplains of Angkor, and become a prototype for high-density urban centres at the height of the Khmer Empire.

\section{Conclusions}

This research set out to test the hypothesis, based on inscriptional and architectural evidence, that an eighth- to ninth-century AD capital of the Khmer Empire was located on the Phnom Kulen massif. Although the geography of the area creates specific challenges for identifying an Angkorian urban area, the lidar data, supported by additional evidence from archaeological survey and excavation, are consistent with this interpretation. We have revealed evidence of a centrally planned urban area, spanning $\sim 40-50 \mathrm{~km}^{2}$ of the plateau. This comprises a network of major thoroughfares that divide a central zone into a city grid; a system of smaller-scale land parcelling that subdivides city blocks within that grid; a distribution of small shrines, mounds and ponds; a large-scale water-management system, consisting of dams and a major, unfinished reservoir; and finally, a distinctive spatial arrangement of a royal palace, state pyramidtemple and other infrastructural elements that are consistent with—and unique to-all other known Khmer Empire capitals.

In this case, therefore, the archaeological evidence accords with inscriptions that identify Mahendraparvata as the location from which Jayavarman II ruled over the early ninthcentury lands of the Khmer, and is consistent with the definition of a 'capital'. Mahendraparvata is also distinctly 'urban' in the conventional sense. The existence of a palace precinct, a network of thoroughfares and local shrines and neighbourhoods indicate that a royal court was located here and supported by a substantial population of specialised ritual, administrative and other staff drawn from a broader community inhabiting an extensive, well-defined, built-up area. This area was clearly not rural in character, as it has no identifiable agricultural systems; furthermore, its extensive system of parcelled neighbourhoods indicate that it was not merely a vacant ceremonial centre.

These results also have significance for broader issues and debates in the archaeology of the Angkorian world. As at Koh Ker (Evans 2010), we have evidence of a large urban area with an

(C) Antiquity Publications Ltd, 2019 
elaborate system of hydraulic infrastructure, which-contrary to the prevailing 'hydraulic city' theory concerning the rise of Angkor (Coe \& Evans 2018) — seems not to be designed for irrigated rice agriculture. As at Koh Ker, however, the inadequacy of the watermanagement system for intensive rice agriculture at Mahendraparvata could either be seen as an argument against the 'hydraulic city' hypothesis (Lustig et al. 2018), or, alternatively, as an explanation for the ephemeral nature of Mahendraparvata as the seat of power. Further research is required to resolve the question.

The new map of Mahendraparvata presented here is also relevant to debates about the development of urban form in the Khmer context. Previous work on urbanism at Angkor has noted two distinct forms: formally planned, densely inhabited urban centres, characterised by city grids with spaces constrained by walls and enclosures; and beyond that, lowdensity, mixed urban-agrarian landscapes with occasional nodes of high-density occupation (Evans et al. 2013; Evans 2016). Mahendraparvata combines features of both, while missing many other elements. It has an extended city grid, but without any attempt to define a central area with a wall or moat; the central grid does not appear to have been densely inhabited; and there is little evidence for intensive agricultural activity or a broader network of low-density occupation revolving around fields and ponds. Hence, while Mahendraparvata is immediately recognisable as Angkorian, and identifiably 'urban', it is totally unique in the Khmer world in its development of urban form. We note also that the urban network of Phnom Kulen is embedded within the fabric of Greater Angkor (Figure 1), and remained so for centuries (Penny et al. 2014). Yet its unique morphology remained intact, even as other parts of that settlement complex developed along distinctly different trajectories (Figure 8). Consistent with other recent work on tropical urbanism in the Khmer and the Maya homelands (Fletcher 2009; Canuto et al. 2018), the landscape-scale perspective afforded by lidar compels us to revisit conventional notions of urban environments as neatly defined, welldelineated and densely inhabited spaces, and to consider them instead as components of a messy and complex continuum of urban and rural space.

We now have complete lidar coverage of the forested areas in the Angkor region, and it is clear that Mahendraparvata is the last component of that vast settlement complex to emerge from beneath the canopy. The work described here effectively draws to a close 150 years of archaeological mapping work in the Greater Angkor region and sets the stage for more sophisticated spatio-temporal modelling of urban form. By incorporating new data from Angkorian household archaeology (Carter et al. 2018), we should soon be able to construct finer-grained demographic models and finally resolve basic questions concerning the extent and population of Angkor, and how that changed over the centuries.

\section{Acknowledgements}

This research was funded by the Archaeology and Development Foundation and by the European Research Council (ERC) under the European Union's Horizon 2020 research and innovation programme (grant agreement 639828). Lidar data were acquired as part of the Khmer Archaeology LiDAR Consortium and the Cambodian Archaeological Lidar Initiative. We are grateful for the support and assistance of all of the participating organisations, companies and their staff-in particular the APSARA National Authority, the Cambodian Ministry of Culture and Fine Arts, and PT McElhanney Indonesia. Datasets reported here are archived at the Angkor International Research and Documentation Centre, Siem Reap, Cambodia.

(C) Antiquity Publications Ltd, 2019 


\section{References}

Aymonier, É. 1900. Le Cambodge: le royaume actuel. Paris: Ernest Leroux.

- 1904. Le Cambodge: le groupe d'Angkor et l'histoire. Paris: Ernest Leroux.

Boulbet, J. 1979. Le Phnom Kulen et sa région: carte et commentaire. Paris: École française d'Extrême-Orient.

Boulbet, J. \& B. Dagens. 1973. Les sites archéologiques de la région du Bhnam Gûlen (Phnom Kulen). Arts Asiatiques 27. https://doi.org/10.3406/arasi.1973.1069

Canuto, M.A. et al. 2018. Ancient lowland Maya complexity as revealed by airborne laser scanning of northern Guatemala. Science 361: eaau0137. https://doi.org/10.1126/science.aau0137

Carter, A., P. Heng, M. Stark, R. Chhay \& D. Evans. 2018. Urbanism and residential patterning in Angkor. Journal of Field Archaeology 43: 492-506.

https://doi.org/10.1080/00934690.2018.1503034

Chevance, J.-B. 2011. Le Phnom Kulen à la source d'Angkor, nouvelles données archéologiques. Unpublished $\mathrm{PhD}$ dissertation, Université Sorbonne Nouvelle-Paris 3.

- 2013. Pœng Tbal et Pœng Eisei, ermitages angkoriens méconnus du Phnom Kulen. Aséanie 32: 11-76.

- 2014. Inscriptions du Phnom Kulen: corpus existant et inscriptions inédites, une mise en contexte. Bulletin de l'École française d'Extrême-Orient 100: 201-30. https://doi.org/10.3406/befeo.2014.6173

- 2015. Banteay, palais royal de Mahendraparvata. Aséanie 33: 279-330.

Coe, M. \& D. Evans. 2018. Angkor and the Khmer civilization. London: Thames \& Hudson.

Evans, D. 2010. The archaeological landscape of Koh Ker, northwest Cambodia. Bulletin de l'École française d'Extrême-Orient 97-98: 91-150. https://doi.org/10.3406/befeo.2010.6130

- 2016. Airborne laser scanning as a method for exploring long-term socio-ecological dynamics in Cambodia. Journal of Archaeological Science 74: 164-75. https://doi.org/10.1016/j.jas.2016.05.009

Evans, D. \& R. Fletcher. 2015. The landscape of Angkor Wat redefined. Antiquity 89: 1402-19. https://doi.org/10.15184/aqy.2015.157

Evans, D., C. Pottier, R. Fletcher, S. Hensley, I. Tapley, A. Milne \& M. Barbetti. 2007. A

(C) Antiquity Publications Ltd, 2019 comprehensive archaeological map of the world's largest preindustrial settlement complex at Angkor, Cambodia. Proceedings of the National Academy of Sciences of the USA 104: 14277-82. https://doi.org/10.1073/pnas.0702525104

Evans, D. et al. 2013. Uncovering archaeological landscapes at Angkor using lidar. Proceedings of the National Academy of Sciences of the USA 110 : 12595-600. https://doi.org/10.1073/pnas.1306539110

FInOT, M. 1911. Sur quelques traditions indochinoises. Bulletin de la Commission Archéologique de l'Indochine 8: 20-37.

Fletcher, R. 2009. Low-density, agrarian-based urbanism: a comparative view. Insights 2: 1-19.

Gaucher, J. 2017. L'enceinte d'Angkor thom: archéologie d'une forme, chronologie d'une ville, in A. Beschaouch, F. Verellen \& M. Zink (ed.) Deux décennies de coopération archéologique franco-cambodgienne à Angkor: 27-41. Paris: Académie des Inscriptions et Belles-Lettres.

Hansen, E. 1969. Aménagement du Phnom Kulen. 1478/BMS. RD/CLT. Paris: UNESCO. Available at: https://www.aefek.fr/wa_files/hansen_ phnomkulen.pdf (accessed 7 August 2019).

JaCQues, C. \& P. LAFOND. 2007. The Khmer Empire: cities and sanctuaries, fifth to thirteenth century. Bangkok: River.

Kokalj, Ž. \& R. Hesse. 2017. Airborne laser scanning raster data visualization: a guide to good practice. Ljubljana: Založba ZRC. Available at: http://zalozba.zrc-sazu.si/p/P14 (accessed 7 August 2019).

Kummu, M. 2009. Water management in Angkor: human impacts on hydrology and sediment transportation. Journal of Environmental Management 90: 1413-21.

https://doi.org/10.1016/j.jenvman.2008.08.007

Lustig, T., S. Klassen, D. Evans, R. French \& I. MofFat. 2018. Evidence for the breakdown of an Angkorian hydraulic system, and its historical implications for understanding the Khmer Empire. Journal of Archaeological Science: Reports 17: 195-211. https://doi.org/10.1016/j.jasrep.2017.11.014

Penny, D., J.-B. Chevance, D. Tang \& S. De Greef. 2014. The environmental impact of Cambodia's ancient city of Mahendraparvata (Phnom Kulen). PLoS ONE 9: e84252. https://doi.org/10.1371/journal.pone.0084252 
Pottier, C. 2012. Beyond the temples: Angkor and its territory, in A. Haendel (ed.) Old myths and new approaches: interpreting ancient religious sites in Southeast Asia: 12-27. Clayton: Monash University.

- 2017. Nouvelles données sur les premières cités angkoriennes, in A. Beschaouch, F. Verellen \& M. Zink (ed.) Deux décennies de coopération archéologique franco-cambodgienne à Angkor: 43-79. Paris: Académie des Inscriptions et Belles-Lettres.

Shimoda, I. 2010. Study on the ancient Khmer City Isanapura. Unpublished $\mathrm{PhD}$ dissertation, Waseda University, Tokyo.

Singh, M., D. Evans, J.-B. Chevance, B.S. Tan, N. Wiggins, L. Kong \& S. Sakhouen. 2018. Evaluating the ability of community protected forests in Cambodia to prevent deforestation and degradation using temporal remote sensing data. Ecology and Evolution 8: 10175-91. https://doi.org/10.1002/ece3.4492
Stark, M.T., D. Evans, R. ChHay, P. Heng \& A. Carter. 2015. Residential patterning at Angkor Wat. Antiquity 89: 1439-55. https://doi.org/10.15184/aqy.2015.159

STERN, P. 1932. La transition de l'art préangkoréen à l'art angkoréen et Jayavarman II, in Études d'orientalisme publiées par le Musée Guimet à la mémoire de Raymonde Linossier: 507-23. Paris: Ernest Leroux.

- 1936. Chronique. Bulletin de l'École française d'Extrême-Orient 36: 629-30.

- 1938. Travaux exécutés au Phnom Kulên (15 avril20 mai 1936). Bulletin de l'École française d'Extrême-Orient 38: 151-73. https://doi.org/10.3406/befeo.1938.4718

Uchida, E. \& I. Shimoda. 2013. Quarries and transportation routes of Angkor monument sandstone blocks. Journal of Archaeological Science 40: 1158-64.

https://doi.org/0.1016/j.jas.2012.09.036

Received: 3 January 2019; Revised: 24 January 2019; Accepted: 11 February 2019 